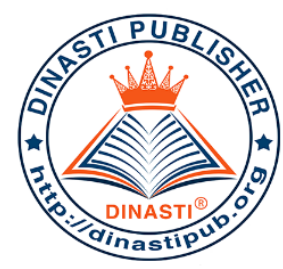

\title{
MOTIVATION ANALYSIS OF CROWDFUNDING DONATION BASED DISCLOSURE
}

\section{Ruli Bestari'), Yan Rahadian ${ }^{2}$}

${ }^{1,2)}$ Universitas Indonesia, Jakarta, Indonesia

\section{ARTICLE INFORMATION}

Received: 1 February 2020

Revised: 15 February 2020

Issued: 20 February 2020

Corresponding Author:

Ruli Bestari

\section{E-mail:}

bestrulibest@gmail.com

yan.rahadian@yahoo.com

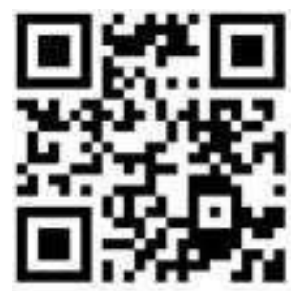

DOI:10.31933/DIJDBM
Abstract: This study aimed to understand the degree of accountability related to disclosure of online donation crowdfunding report and provide some recommendation for adequate disclosure of crowdfunding online donation from stakeholder. This study is motivated by the fact that cyber scam of online donation increased and absence spesific regulation about donation crowdfunding from regulator to mitigate. Signaling theory and stakeholder theory are applied in this study. Two different approaches to asses motivation of online donation crowdfunding disclosure, such as the self enlightened interest consider as ethical business and genuine accountability as mandatory business. Kitabisa.com choosen as single unit analysis for this study. This study employee mixed method with content and thematic analysis processed by Nvivo 12 pro. It is found that self enlightened interest still dominant and play important role in Kitabisa.com disclosure report. Recommendations for disclosure from donors to answer where is their money go such as campaign detail description, publication or clarification, campaign detail financial report, time limit for disclose campaign report, recap or plan for funding utilization, interaction between donors and campaigner and add visual document to reduce assymetri information and strength stakeholder engagement.

Keywords: Online Donation Crowdfunding, Signal Theory, Stakeholder Theory, Self Enlightened Interest, Genuine Accountability, Disclosure 


\section{INTRODUCTION}

The development of crowdfunding-based online donations has become one of the millennial trends in donating funds. The popularity of fundraising through crowdfunding has grown rapidly in recent years (Sulaeman \& Lin, 2018). Online based crowdfunding-donation based began with the founding of donorchoose.org in 2000. Donorchoose.org is crowdfunding about providing classes for students who need teaching. Furthermore, Kiva was formed in 2005 in San Fransisco to help communities who can not access funding through banks. Indiegogo established in 2008 by Danae Ringelman, Eric Schell, and Slava Rubin. Approximately, 19.000 campaigns have been successfully funded. In 2009, Kickstarter was established which has helped fund 158.473 projects. As revealed on its official website, sixteen million people have actively contributed to donations and have raised US $\$ 4.1$ billion in funds. Kickstarter is transformed into a benefit-based corporation.

Crowdfunding online grow to Asian continent in line with development of crowdfunding online in the world. GIVE.ASIA, a crowdfunding-based online donation in Singapore, has raised more than SGD37 million, with nearly 1.3 million donors and 11,550 campaigns(www.give.asia.com). India has a Ketto state that has managed to raise 300 Crore funds, 2.5 million donors, and approximately 80 thousand funders (www.ketto.org). Japan has Campfire which was founded in 2011 and is said to be a Japanese Kickstarter. Campfire managed to collect approximately JPY300 million (www.campfire.co.jp).

Then crowdfunding-based online donations were also born in Indonesia. One of the most popular crowdfunding-based online donation sites in Indonesia is Kitabisa.com. Since it was founded in 2013, Kitabisa.com has managed to raise nearly Rp 600 billion in funds with more than 20 thousand campaigns funded by 1.6 million donors called good people (www.Kitabisa.com). The operationalization of crowdfunding-based online donations is more flexible than other forms of crowdfunding that have financial reciprocity to the community (Paschen, 2017)

In crowdfunding-based online donations, there are no returns or prizes to contributors (Paschen, 2017). The absence of tangible returns given to these contributors poses a risk to donors that is related to the truth and accuracy of the distribution of donation funds. A survey conducted by Symantec published in the 2016 Internet Security Threat Report showed that Indonesia was in the 10th position in the Asia Pacific for social media fraud cases. One phenomenon of crowdfunding-based online donation abuse in Indonesia is the case of misuse of funds by Cak Budi in 2017. Cak Budi uses donation funds to buy personal assets namely luxury cars and cellphones as quoted by CNN Indonesia (2017). Until finally the Ministry of Social Affairs closed the fundraising account as sanctions.

However, disclosures related to the fulfillment of donor rights have not been supported by applicable regulations. In Indonesia, the government, through the Ministry of Social Affairs, has not specifically regulated the collection of goods and money for crowdfunding-based online donations. The applicable regulations are still Law Number 9 of 1961 which has not represented the collection of goods and money via digital and has not explained the rights and obligations of 
donors. The Financial Services Authority (OJK) has not provided specific guidance on crowdfunding-based online donation management. The Indonesian Institute of Accountants (IAI) also has not specifically regulated financial disclosure disclosures for donation-based organizations using digital crowdfunding. Overall, it can be concluded that the relevant regulators, especially in Indonesia, have not yet specifically regulated the provisions for disclosure of financial statements and all activities carried out in accordance with donor rights. If the donor does not have trust in the use of the donation, the donor will stop the donation and even recommend others not to donate.

This research was conducted at Kitabisa.com in Indonesia. Kitabisa.com is the largest online crowdfunding-based donation and is still operating in Indonesia based on an online giving report published in 2018 by Kitabisa.com with funding reaching around Rp 600 billion as of March 2019, 16,000 projects funded, and one million donors involved. This research will involve active donors on the Kitabisa.com website. Meanwhile, for the analysis of data this study used content and thematic analysis. Content analysis uses word frequency and number of references as measurement bases which will give a descriptive picture. The results of the content analysis are continued with thematic analysis. This approach was used to determine the themes or issues that emerged in this study

Based on the background above, the formulation of the questions to be answered in this study are:

1) How is the motivation for disclosure of activity, financial, and project reports on Kitabisa.com viewed from the perspective approach of self-enlightened and genuine accounting models?

2) What are the recommendations for disclosure of financial statements, projects, and activities on Kitabisa.com to mitigate information asymmetries?

\section{LITERATURE REVIEW}

This study use signal theory and stakeholder theory. Signal theory breakdown by two approaches, such as self enlightened interest and genuine accountability. This approaches use to asses motivation od donation based crowdfunding disclosure. Signal theory becomes very instrumental in reducing the risk of asymmetric information in investment decisions and has been proven to be a consideration in determining decisions in crowdfunding companies (Ahlers et al (2015), Lin et al (2013), and Moss et al (2014) in Moleskis et al., (2018) In the area of nonprofit organizations, in-depth investigation of campaigns and the characteristics of non-profit organizations can increase the amount and volume of funding obtained by disclosing information signals (Moleskis et al., 2018). Lin (2018) explains that potential donors look for signal quality information provided by fund campaigners such as the purpose of campaign funding and the characteristics of campaign descriptions.

This signal theory is used to assess disclosure motivations made by crowdfunding-based online donations. The information signal revealed by crowdfunding-based online donations is assessed using the self-enlightened interest and genuine accountability approaches. This 
motivation analysis uses published documentation data instruments including audited financial reports, online giving reports, and press releases which can be accessed on the official website of Kitabisa

The self-enlightened interest model was introduced by Wallich and McGowan (1970) which was continued by Keim (1978), as quoted by Shauki (2011). This model was developed from signal theory. This model states that corporate social responsibility is carried out as a business interest to carry out activities that are beneficial to the community and the environment which will ultimately benefit shareholders or business owners. Deegan (2009) in Shauki (2011) states that the self-interest interest model is a model where the company (only) will carry out activities where the discounted profit flow is reduced by a discounted cost greater or equal to alternative opportunities for investment.

In contrast, the genuine accountability model introduced by Berman et al (1999) is based on stakeholder theory (Shauki, 2011). This model assumes that corporate reporting is based on responsibility or accountability, not on demand. Schlenker et al (1994), as cited in Shauki (2011), states that accountability is a responsibility for the condition of the company to the public about performance according to standards including the fulfillment of responsibilities, obligations, expectations, and other rewards. Merkl-Davies (2011) in Shauki (2011) states that accountability is the obligation of one party to provide explanations and justifications to the other party.

The influence of stakeholders on disclosure can also be applied in the context of information disclosure by crowdfunding-based companies. There is a similarity in the context of social disclosure by companies with the context of information disclosure by crowdfundingbased companies which are non-profit organizations. The main information on crowdfundingbased companies is social information about managing funds from donors who are the main stakeholders. Therefore disclosure of accountability for managing funds by crowdfunding-based companies can also be explained by stakeholder theory. The role of crowdfunding-based companies differs from traditional traditional financial institutions because crowdfunding tends to have many contextual competitors and stakeholders (Valančienè \& Jegelevičiūtè, 2014). Understanding this shifting of stakeholder roles becomes very important to determine success in creating value for stakeholders by satisfying stakeholders. Therefore it is necessary to know the phenomena, interests, needs, and expectations of stakeholders in order to satisfy stakeholders (Valančienè \& Jegelevičiūt 2014, 2014).

\section{RESEARCH METHODS}

This research is a case study research. Case study research is research that focuses on a particular case to be observed and analyzed thoroughly until it is complete. The case study in Sekaran and Bougie (2013) is a qualitative research technique that is useful for obtaining a clear picture of a problem in a real situation from several perspectives using several data collection methods. Case studies focus on gathering information about specific objects, activities or activities, such as specific businesses or organizations (Sekaran and Bougie, 2013). The 
question "how" and "why" can be better explained and better used research based on case studies, history, and experiments (Yin, 2009).

Case studies are chosen as an approach to research and answer specific and complex issues in a single case that focuses on a particular issue or problem. The unavailability of standard regulations and guidelines regarding public disclosure has an impact on the variety of forms of disclosure of activity reports, project reports, and financial reports on crowdfundingbased online donations. The case study is expected to be a research approach that can analyze in depth the disclosure motivation with the approach of self-interest interest and genuine accountability.

This research uses a combination of qualitative and quantitative methods. The method used combines qualitative data that is text based data and not in term of numbers and quantitative data that is data that is numeric in nature. This combination method was chosen to answer the problem formulation with the question why and how (qualitative) and in answering the problem statement supported by numerical (quantitative) data. This combination method is represented by the process of interviews, discussions and analysis of financial report data archives, information provided both verbally and non-verbally, and information contained on the company's website.

The data used in this study are primary data and secondary data. Primary data derived from data from interviews of active donors Kitabisa.com. Secondary data in this study were obtained from financial report data archives and all other supporting information published online

Criteria for interview respondents as follows:

a. Age range of donors aged 25-40 years;

b. Donated at Kitabisa.com more than 1 time a donation;

c. Having a job or earning an active income; and

d. Active internet users with at least 1 (one) social media account

Documentation and interview data will be analyzed using content analysis and thematic Content analysis is a method often used in empirical data collection (Parker, 2005). According to Cole (1988) in Shauki (2011), content analysis is a method for analyzing written, verbal, or visual communication messages. Content analysis was chosen to answer the company's motivation to disclose financial statements, activities and projects through a self-enlightened interest approach and genuine accounting model and is used to analyze content or topics that are often discussed by donors based on interview data. Quantitative, conceptual or thematic content analysis is used to find the main themes and this analysis forms a qualitative product.

Content analysis investigation instruments to assess disclosure motivation on crowdfunding-based online donation sites are distinguished based on the theme or code as follows:

a. Genuine accountability

The development of genuine accountability codes / topics is based on that the genuine 
accountability approach refers to compliance or mandatory regulations that must be obeyed and not based on stakeholder requests but based on obligations that really should be disclosed as reporting standards

1) Compliance (punishment; policy; clarification; community; rules; principle; regulation; sanctions; report; foundation)

2) Accountability (assets; finance; recording; recognition; accounting; finance)

b. Self-enlightened interest

The development of codes / topics for self-enlightened interest refers to business ethics for disclosure of voluntary matters that aim to provide information assurance to stakeholders regarding the use of donations and company operations. Self-enlightened interest is expected to increase stakeholder engagement so that business can be carried out sustainably.

(1) Donations (donors; campaigns; satisfaction)

(2) Humanity (help; good people)

(3) Disclosure of information (community; growth; program; campaign; social; responsibility; testimony; transparency

The unit of analysis in this study is the single unit of analysis conducted on Kitabisa.com. Kitabisa.com was chosen as the unit of analysis because Kitabisa.com is an online crowdfunding-based online donation site that has survived with the largest funding achievement and most donors in Indonesia until 2019 since Realize and Ayopeduli closed its site.

\section{RESULTS AND DISCUSSIONS}

Table. 1 Percentage of motivation disclosure

\begin{tabular}{|c|c|c|c|c|c|}
\hline \multicolumn{2}{|c|}{ Annual Report 2017-2018 } & \multicolumn{2}{|c|}{$\begin{array}{c}\text { Online Giving Report } \\
\text { 2016-2018 }\end{array}$} & \multicolumn{2}{|c|}{ Press Release } \\
\hline$f$ & nuine & $f$ & nuine & $f$ & nuine \\
\hline $\begin{array}{l}\text { Enlightene } \\
d \text { Interst }\end{array}$ & Accountability & $\begin{array}{l}\text { Enlightene } \\
\text { d Interst }\end{array}$ & Accountability & $\begin{array}{l}\text { Enlightene } \\
\text { d Interst }\end{array}$ & Accountability \\
\hline $7.14 \%$ & $92.85 \%$ & $91.67 \%$ & $8.33 \%$ & $97.29 \%$ & $2.71 \%$ \\
\hline
\end{tabular}

Source : NVivo processing data

Table 1 shows the percentage of domains of self-enlightened interest and genuine accountability obtained from the coding system on themes / topics and word frequency by domain. Disclosures in the Audited Financial Statements use a genuine accountability model approach with a percentage of almost 93\%, compared to the self-enlightened interest approach with a percentage of only about 7\%. This indicates that in the Audited Financial Statements, Kitabisa.com discloses reports as a form of compliance and accountability accountability for assets, cash flow, recognition, accounting principles, and accounting policies. The target of audited financial statements is not only for donors as disclosure of campaign information updates but for the benefit of stakeholders outside the donor. The Audited Financial Report is one of the media for the delivery of information that is used as a basis for consideration of 
strategic decision making so that the information disclosed is forms of disclosure of compliance standards for a Foundation organization.

Table 1 also presents the percentage of disclosure in the online giving report Kitabisa.com. The highest percentage is the self-highlighted interest model, which is almost $92 \%$, while the genuine accountability model is only around $8 \%$. This indicates that the online giving report is one of the media to provide disclosures related to campaigns (types and forms), humanity, information updates, use of funds, humanity, and campaign programs. Online giving report is a publication report that aims to provide a year-long review of the activities carried out by Kitabisa.com. The information disclosed emphasizes more on the sustainability of the organization. This report aims to increase donor trust so that it is expected to reduce anxiety and increase donor retention. Therefore the information disclosed refers to the self-enlightened interest model, which discloses information so that the organization's existence and branding are more reliable and good.

Furthermore, Table 1 also explains the percentage of disclosure models used in press releases published through the official website ofisaisa.com. Press release data was taken from 2016 until the last time it was accessed when the research began. The disclosure model with the biggest percentage is self enlightened interest, which is more than 97\%. A press release report is a more detailed report for each campaign, clarification of reporting on Kitabisa.com, use of funds, campaign collaboration, and donor education. The clarification of Kitabisa.com regarding the misuse of funds by Cak Budi was revealed in the press release report as a form of responsibility and return of the good name of the organization.

Press releases are intended as a media of information and a media bridge between donors and Kitabisa.com regarding detailed information updates. The aim of the press release is not only to focus on the Kitabisa.com donors, but to all site visitors in general so that the information disclosed can give attention to visitors to make donations on Kitabisa.com.

Reports on activities, campaigns, projects and donations are delivered through a press release. Kitabisa.com uses press release as a form of "well disclosed by doing well". Kitabisa.com intends to reveal that they have carried out activities properly and correctly to guarantee the trust of donors and answer the concerns of donor questions about "where their funds are and whether the funds are channeled correctly and correctly". When donors have trust, donation retention will increase which will ultimately increase donations on Kitabisa.com

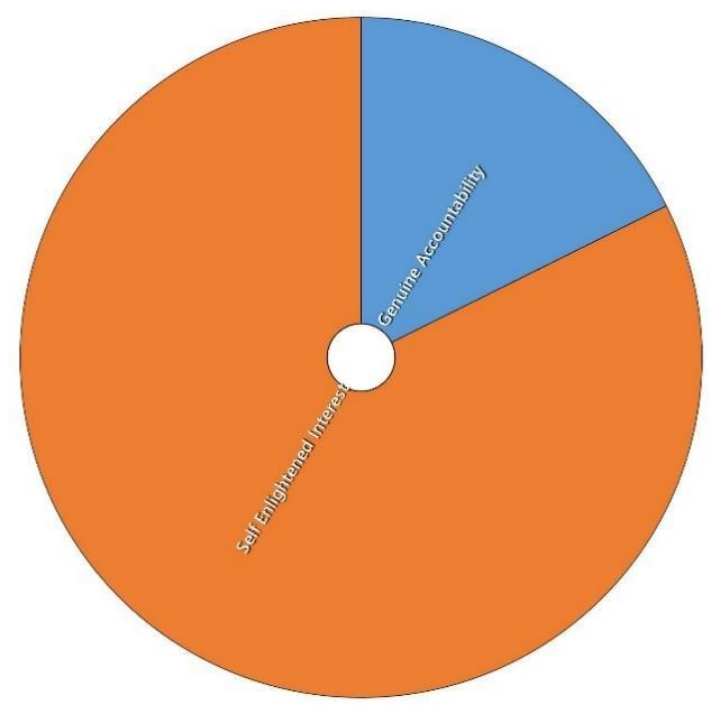




\section{Picture 1. Composition of Disclosure motivation for All disclosure report \\ Source : NVivo processing data}

Picture 1 illustrates the conclusion of motivation for information disclosure by Kitabisa.com through the media of Audited Financial Statements, online giving reports, and press releases. Kitabisa.com combines a self-enlightened interest approach and genuine accountability in disclosing information about financial statements, campaigns, and projects. The self-enlightened interest model occupies a dominant position and provides a large role in motivating Kitabisa.com to publish financial reports, activities and campaigns to stakeholders. The genuine accountability model plays a large role in the Audited Financial Statements and self-enlightened interest plays a large role in online giving reports and press releases. This difference in motivation indicates that the disclosure motivation is influenced by the target / target segment of the report issued. Overall, it can be concluded that the self-enlightened interest model has a large role in disclosing reports that are publicly accessible.

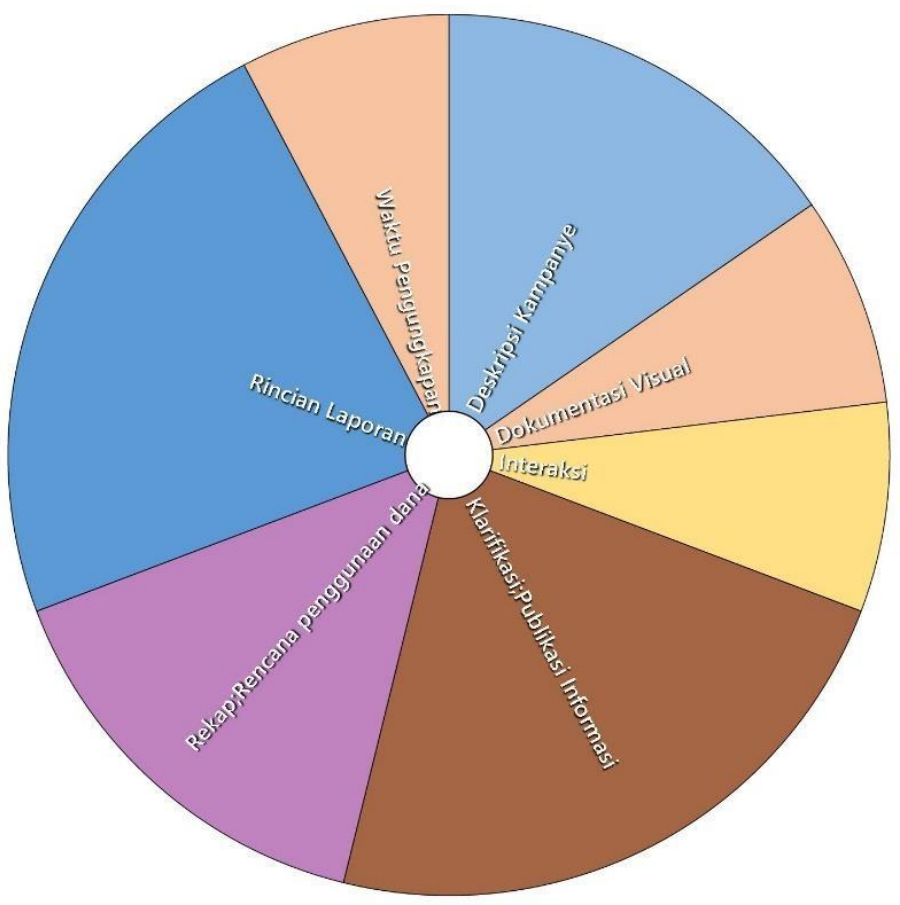

\section{Picture 2. Recommendation disclosure from donor}

Source : NVivo processing data

Analysis of content and themes on the results of interviews with donors as respondents shows recommendations for disclosure from donors to guarantee and answer 'where their funds go" includes: (1) presentation of campaign descriptions, (2) clarification; publication, (3) details of each campaign report, (4) deadline for disclosure of campaign funds, (5) recap; planned use of funds, (6) interaction between donors and campaigners, and (7) visual documentation. Kitabisa.com has revealed information about campaign descriptions, clarifications, and publications. Kitabisa.com can improve the quality of information disclosed by meeting five other recommendations

We conclude that, it can be said that the time limit for disclosure of campaign funds, features of interaction between donors and campaigners, and visual documentation are things suggested by donors to be included in financial statements, campaign activities and projects on 
Kitabisa.com. Such disclosure can be taken into consideration by Kitabisa.com to fulfill the rights or interests of donors and increase donor trust to mitigate the risk of asymmetric information.

\section{CONCLUSION AND SUGGESTION}

Analysis of content and themes at the publication sources in the form of Audited Financial Statements 2017-2018, online giving report 2016-2018, and accessible press releases, shows that the motivation of Kitabisa.com in disclosing information is a combination of the approach of the genuine accountability model and the self-enlightened interest model. In the Audited Financial Statements, Kitabisa.com's motivation is consistent with the approach of genuine accountability compared to self-enlightened interest. On the other hand, in online giving reports and press releases, the motivation of Kitabisa.com is consistent with its self-enlightened interest approach. Overall publications, self-enlightened interest motivation has a composition greater than genuine accountability. In other words, the self-enlightened interest approach has a large role in the disclosure pattern of Kitabisa.com.

Analysis of content and themes on the results of interviews with donors as respondents shows recommendations for disclosure from donors to guarantee and answer "where their funds go" includes: (1) presentation of campaign descriptions, (2) clarification; publication, (3) details of each campaign report, (4) deadline for disclosure of campaign funds, (5) recap; planned use of funds, (6) interaction between donors and campaigners, and (7) visual documentation. Kitabisa.com has revealed information about campaign descriptions, clarifications, and publications. Kitabisa.com can improve the quality of information disclosed by meeting five other recommendations

Comparative analysis between disclosures that have been disclosed by Kitabisa.com compared to recommendations for disclosure from the donor side is found that Kitabisa.com should consider adding disclosures related to the time limit of the disclosure of the report from the campaigner, the interaction features between the donor and the campaigner, and visual documentation for each campaign. This additional disclosure is expected to provide trust to donors so that they can mitigate asymmetric information.

The practical implication of this research is to provide an evaluation and illustration to be taken into consideration for Kitabisa.com in making disclosures in accordance with donor expectations. In addition to Kitabisa.com as a donation-based crowdfunding, this research has implications in the form of regulatory considerations in formulating policies or regulations regarding disclosure matters that must be disclosed by donation-based crowdfunding so as to mitigate information between crowdfunding and donors.

This study has several limitations. The study did not use disclosure through online media outside the official website of Kitabisa.com. This research focuses on the intention to disclose internally. This study also did not conduct interviews with the Kitabisa.com. Sources of disclosure are examined through publications document sources that are publicly accessible. 
Interviews were also only conducted to one of the main stakeholders namely the donor Kitabisa.com. This study also only uses a single unit of analysis namely Kitabisa.com and there is no comparative analysis unit.

In the next research, it can use multi-unit analysis to compare the disclosure motivation conducted by various crowdfunding in Indonesia. The disclosure instruments analyzed can also be expanded, not only using disclosure instruments sourced from internal sources but also using disclosures from external sources of the organization. Future studies are expected to not only use documentation data but also use primary data in the form of interviews with companies and stakeholders from the campaigning side not only from the donor side 


\section{REFERENCE}

Ahlers, G. K. C., Cumming, D., Günther, C., \& Schweizer, D. (2015). Signaling in Equity Crowdfunding. Entrepreneurship: Theory and Practice, 39(4), 955-980. https://doi.org/10.1111/etap.12157

Althoff, T., \& Leskovec, J. (2015). Donor retention in online crowdfunding communities: A case study of DonorsChoose.org. In Proceedings of the 24th International Conference on World Wide Web (pp. 34-44). https://doi.org/10.1145/2736277.2741120

Azizah, Rizka. (2016, Agustus 30).Hati Hati, modus penipuan berkedok donasi. https://www.femina.co.id/trending-topic/hati-hati-modus-penipuan-berkedok-donasi. Diakses tanggal 10 April 2019.

Beaulieu, T., Sarker, S., \& Sarker, S. (2015). A Conceptual Framework for Understanding Crowdfunding. Cais, 37(June), 1.

Becker, A. (2018). An experimental study of voluntary nonprofit accountability and effects on public trust, reputation, perceived quality, and donation behavior. Nonprofit and Voluntary Sector Quarterly, 32, 596-615. https://doi.org/10.1177/0899764018756200

Bekkers, R. (2003). Trust, accreditation, and philanthropy in the Netherlands. Nonprofit and Voluntary Sector Quarterly, 32(4), 596-615. https://doi.org/10.1177/0899764003258102

Bougie \& Sekaran. (2013). Research Methods for Business: A skill Building Approach.New York : John wiley@Sons

Block, J., Hornuf, L., \& Moritz, A. (2018). Which updates during an equity crowdfunding campaign increase crowd participation? Small Business Economics, 50(1), 3-27. https://doi.org/10.1007/s11187-017-9876-4

Chiu, T. K., \& Wang, Y. H. (2014). Determinants of social disclosure quality in taiwan: an application of stakeholder theory. Journal of Business Ethics, 129(2), 379-398. https://doi.org/10.1007/s10551-014-2160-5

Colasanti, N., Frondizi, R., \& Meneguzzo, M. (2018). Higher education and stakeholders' donations: successful civic crowdfunding in an Italian university. Public Money and Management, 38(4), 281-288. https://doi.org/10.1080/09540962.2018.1449471

Courtney, C., Dutta, S., \& Li, Y. (2016). Resolving nformation asymmetry: signaling, endorsement, and crowdfunding success. Entrepreneurship: Theory and Practice, 41(2), 265-290. https://doi.org/10.1111/etap.12267

Elijido-ten, E. (2004). Determinants of environmental disclosures in a developing country: an application of the stakeholder theory. In Fourth Asia Pacific Interdisciplinary Research in Accounting Conference (pp. 1-28).

Gregorian, Dareh. (2018,November 16).Arrest in GoFundMe homeless good samaritan scam show perils of crowdfunding. https://www.nbcnews.com/news/us-news/arrests-gofundmehomeless-good-samaritan-scam-show-perils-crowdfunding-n936941. Diakses tanggal 
05September 2018 .

Hamidi.(2004). Metode Penelitian Kualitatif : Aplikasi Praktis Pembuatan Proposal dan Laporan Penelitian. Malang:UMM Press

Heikkinen, A., Kujala, J., \& Inha, M. (2019). Stakeholder engagement in a non-profit organisation: an issue-based perspective. Int. J. Human Resources Development and Management, 19(1), 5-20.

Huang, C. L., \& Kung, F. H. (2010). Drivers of environmental disclosure and stakeholder expectation: evidence from Taiwan. Journal of Business Ethics, 96(3), 435-451. https://doi.org/10.1007/s10551-010-0476-3

Kim, J., Newberry, P., \& Qiu, C. (2018). The role of information signals in determining crowdfunding outcomes. In Digital economic conference (pp. 23-51).

Kim, P. H., Buffart, M., \& Croidieu, G. (2016). TMI: signaling credible claims in crowdfunding campaign narratives. Group and Organization Management, 41(6), 717-750. https://doi.org/10.1177/1059601116651181

Kusumawati, Dewi.(2017).Pengaruh stakeholder engagement terhadap pengungkapan sustainability report berdasarkan global reporting intiative (GRI) G4 (Studi empiris pada perusahaan non-Keuangan yang terdapat di BEI tahun 2013-2015. Fakultas ekonomi dan Bisnis. Universitas Lampung. Lampung

Li, X., Tang, Y., Yang, N., Ren, R., Zheng, H., \& Zhou, H. (2016). The value of information disclosure and lead investor in equity-based crowdfunding. Nankai Business Review International, 7(3), 301-321. https://doi.org/10.1108/NBRI-01-2016-0002

Moleskis, M., Alegre, I., \& Canela, M. A. (2018). Crowdfunding entrepreneurial or humanitarian needs? the influence of signals and biases on decisions. Nonprofit and Voluntary Sector Quarterly, 48(3), 552-571. https://doi.org/10.1177/0899764018802367

Novitasari, Sisilia Claudea. (2017,Mei 05). Cerita Cak Budi Buka-bukaan soal aksinya pakai uang donasi. https://www.cnnindonesia.com/nasional/20170505002637-20-212420/ceritacak-budi-buka-bukaan-soal-aksinya-pakai-uang-donasi. Diakses tanggal 01 Januari 2019

O’Neil, J. (2007). The link between strong public relationships and donor support. Public Relations Review, 33(1), 99-102. https://doi.org/10.1016/j.pubrev.2006.11.021

Paschen, J. (2017). Choose wisely: crowdfunding through the stages of the startup life cycle. Business Horizons, 60(2), 179-188. https://doi.org/10.1016/j.bushor.2016.11.003

Rahardjo, Mundjia. (2010). Triangulasi dalam penelitian kualitatif.http://mudjiarahardjo.com/artikel/270.html?task=view.Diakses tanggal 10 Agustus 2018

Roberts, R. W. (1992). Determinants of corporate social responsibility disclosure: An application of stakeholder theory. Accounting, Organizations and Society, 17(6), 595-612. https://doi.org/10.1016/0361-3682(92)90015-K

Saerang,David \& Pontoh Winston.(2011). Analisis pengaruh tingkat pengembalian aktiva 
terhadap harga saham perusahaan di bursa efek indonesia. Jurnal Riset Akuntansi dan Auditing,3(1),3-17. ISSN. 2088-8899

Shauki, E.R.,(2018) Research instruments in case study and the role of researcher.Handout, Case Writing and methodology, ECAM 809303. Universitas Indonesia

Shauki, E. (2011). Is this a case of self-enlightened interst or genuine accountability : a study on different reporting media in the australian retail industry, 2(December), 51-76.

Spence, M. (1973). Job Market Signaling. The Quarterly Journal OfEconomics, 87(3), 355374. https://doi.org/10.1055/s-2004-820924

Sugiyono.(2010).Metode Penelitian Pendidikan Pendekatan Kuantitatif, Kualitatif, dan R\&D. Bandung: Alfabeta

Symantec (2016, April 21).Internet Security Threat Report.April 21.2016. https://www.symantec.com/content/dam/symantec/docs/reports/istr-21-2016-en

Sulaeman, D., \& Lin, M. (2018). Reducing uncertainty in charitable crowdfunding reducing uncertainty in charitable crowdfunding. In Pacific Asia Conference on Information Systems (PACIS) (p. 134).

Valančienè, L., \& Jegelevičiūtè, S. (2014). Crowdfunding for creating value: stakeholder approach. Procedia - Social and Behavioral Sciences, 156(April), 599-604. https://doi.org/10.1016/j.sbspro.2014.11.248

van der Laan Smith, J., Adhikari, A., \& Tondkar, R. H. (2005). Exploring differences in social disclosures internationally: A stakeholder perspective. Journal of Accounting and Public Policy, 24(2), 123-151. https://doi.org/10.1016/j.jaccpubpol.2004.12.007

Yin, R. K. (2009). Case Study Research Design Methods (Third Edit). London: Sage Publication. 